\title{
Economic Development, Sociopolitical Destabilization and Inequality*
}

\author{
Andrey Korotayev \\ $\mathrm{PhD}$, Doctor of Historical Sciences, Professor, Head of the Laboratory of Monitoring of Sociopolitical \\ Destabilization Risks, National Research University Higher School of Economics \\ Senior Research Professor of the Institute of Oriental Studies of the Russian Academy of Sciences \\ Address: Myasnitskaya str., 20, Moscow, Russian Federation 101000 \\ E-mail: akorotayev@gmail.com
}

\section{Leonid Grinin}

Doctor of Sciences, Leading Research Fellow, Laboratory of Monitoring of Sociopolitical

Destabilization Risks, National Research University Higher School of Economics

Senior Research Professor, Institute for Oriental Studies of the Russian Academy of Science Address: Myasnitskaya str., 20, Moscow, Russian Federation 101000

E-mail: lgrinin@mail.ru

\section{Stanislav Bilyuga}

Junior Research Fellow, Laboratory of Monitoring of Sociopolitical Destabilization Risks, National Research University Higher School of Economics Address: Myasnitskaya str., 20, Moscow, Russian Federation 101000 E-mail: sbilyuga@gmail.com

\section{Kira Meshcherina}

Junior Research Fellow, Laboratory of Monitoring of Sociopolitical Destabilization Risks, National Research University Higher School of Economics Junior Research Fellow, Institute for African Studies of the Russian Academy of Sciences Address: Myasnitskaya str., 20, Moscow, Russian Federation 101000

E-mail: k.meshcherina@hotmail.com

\author{
Alisa Shishkina \\ Junior Research Fellow, Laboratory of Monitoring of Sociopolitical Destabilization Risks, \\ National Research University Higher School of Economics \\ Junior Research Fellow, Institute for African Studies of the Russian Academy of Sciences \\ Address: Myasnitskaya str., 20, Moscow, Russian Federation 101000 \\ E-mail: alisa.shishkina@gmail.com
}

\footnotetext{
(C) Korotayev A., 2017

() Grinin L., 2017

(C) Bilyuga S., 2017

(C) Meshcherina K., 2017
}

(c) Shishkina A., 2017

(c) Centre for Fundamental Sociology, 2017

DOI: 10.17323/1728-192X-2017-3-9-35

* This article is an output of a research project implemented as part of the Basic Research Program at the National Research University Higher School of Economics (HSE) in 2017 with support by Russian Science Foundation (Project No. 14-11-00634).

Исследование осуществлено в рамках Программы фундаментальных исследований НИУ ВШЭ в 2017 г. при поддержке Российского научного фонда (проект № 14-11-00634). 
In the 1960s Mancur Olson and Samuel Huntington suggested that the positive correlation between per capita income and the level of sociopolitical destabilization that they detected for low and middle income countries might be partly accounted for by the growth of the inequality associated with the economic and technological development in these countries. The empirical tests we perform generally support this hypothesis, but they also identify certain limits for such an explanation. Our tests reveal for low and middle income countries a statistically significant correlation between GDP per capita and the economic inequality levels, but this correlation is not particularly strong. Earlier we found for the same countries significantly stronger positive correlations between GDP per capita and some important components of sociopolitical destabilization, such as the intensity of political assassinations, general strikes and anti-government demonstrations. It is quite clear that the strong association between the increase in the intensity of these components of sociopolitical destabilization and GDP per capita growth, can be explained by a much weaker tendency toward the growth of economic inequality only partly. In addition, our empirical tests suggest the presence of a certain threshold level of about 40 points on the Gini scale, after crossing which one can expect a radical increase in levels of sociopolitical destabilization in general, and the intensity of terrorist acts / guerrilla warfare and anti-government demonstrations in particular. According to the World Bank, the value of the Gini coefficient for Russia is now just in this zone, which suggests that the further growth of inequality in Russia could lead to an abrupt increase in political destabilization.

Keywords: political instability, sociopolitical destabilization, CNTS destabilization indices, economic development, inequality, GDP per capita

\section{Introduction}

The impact of economic development on sociopolitical destabilization has been the subject of numerous studies. Many of them are based on the seemingly plausible assumption that the higher the level of economic development, the less likely political destabilization (see, for example: Parvin, 1973; Weede, 1981; MacCulloch, 2004; Miguel, Satyanath, Sergenti , 2004; MacCuloch, Pezzini, 2010; DiGiuseppe, Barry, Frank, 2012; Chapman, Reinhardt, 2013; Knutsen, 2014; Mealy et al., 2015) - for a detailed analysis of these works, see our previous publications [Korotayev, Bilyuga, Shishkina, 2016, 2017a, 2016b; Korotayev, Vaskin, Bilyuga, 2017]).

On the other hand, as was shown in Olson (1963) and Huntington (1968), the correlation between per capita incomes and socio-political destabilization is not negative; rather we are dealing with a curvilinear inverted U-shaped ${ }^{1}$ relationship: the highest risks of destabilization exist in the countries with neither the lowest nor the highest, but with the intermediate per capita income (that is, in those countries that are undergoing active modernization processes). Thus, up to a certain value of per capita GDP, economic growth tends to lead to an increase in the risks of socio-political destabilization, and only at its high values (i.e., at the completion of modernization processes) does further growth of GDP per capita lead to a decrease in socio-political instability. Thus, a negative correlation between per capita incomes and the risks of socio-political destabilization

\footnotetext{
1. Note that Huntington himself denoted it as a bell-shaped relationship (1968: 43).
} 
characterizes the higher per capita income range, and a positive one is characteristic of the lower range (Olson, 1963; Huntington, 1968: 39-50).

Our empirical tests using GDP per capita data confirm the existence of such an inverted U-shaped relationship (Korotayev, Issaev, Vasiliev, 2015; Korotayev, Issaev, Zinkina, 2015; Korotayev, Bilyuga, Shishkina, 2016, 2017a, 2017b; Korotayev et al., 2016: Chapter 2; Korotayev, Vaskin, Bilyuga, 2017). In our previous article (Korotayev, Vaskin, Bilyuga, 2017), we show that this curvilinear relationship has quite a different character for different indices of sociopolitical destabilization. However, there is one very important exception. We have shown that the correlation between per capita GDP and intensity of coups and coup attempts is not curvilinear; in this case we are dealing with a clearly pronounced negative correlation (with a particularly strong negative correlation between this index and the logarithm of per capita GDP). This point makes the curvilinear relationship with respect to the integral sociopolitical destabilization index much less impressive and makes a very significant contribution to the formation of its asymmetry (when the negative correlation between per capita GDP and socio-political instability among richer countries looks significantly stronger than the positive correlation for poorer countries). Our earlier analysis shows that for all the other indices of sociopolitical destabilization, we observe a curvilinear inverted U-shaped relationship postulated by the Olson-Huntington hypothesis (Korotayev, Vaskin, Bilyuga, 2017).

With respect to such types of sociopolitical destabilization as general strikes, riots, and anti-government demonstrations, we are dealing with an asymmetry that is directly opposite to what has been mentioned above - with an asymmetry in which the positive correlation between GDP and instability for poorer countries is much stronger than the negative correlation for richer countries. Of special importance is the fact that for the lower range of values of per capita GDP, a particularly strong positive correlation ( $r=$ $0.935, R^{2}=0.875$ ) is found for the relationship between GDP per capita and the intensity of anti-government demonstrations (up to $\$ 20,000$ in 2011 at purchasing power parities [PPP]) (Korotayev, Bilyuga, Shishkina, 2017a, 2017b; Korotayev et al., 2016: Chapters 2, 3; Korotayev, Vaskin, Bilyuga, 2017).

Olson, who first showed a positive correlation between average per capita incomes and the level of political destabilization for low and middle income countries, put forward an explanation for this correlation (in addition to a few other explanations): in the early stages of modernization, the growth of per capita incomes is naturally accompanied by an increase in economic inequality ${ }^{2}$, whereas high economic inequality leads to sociopolitical destabilization (Olson, 1963:536-538) . This seems to be one of the most obvious mechanisms that causes the growth of socio-political instability with an increase in the level of economic development. If the level of economic development in a given society has increased (and so has per capita GDP), but the economic inequality has significantly increased as well, the real incomes of a significant part of the population could have sig-

2. Olson directly refers to the classic work of Simon Kuznets (1956) and provides his own evidence in support of this thesis (Olson, 1963: 536-538).

3. A similar position was held by Huntington (Huntington, 1968). 
nificantly decreased and a significant increase in the wealth of a small part of society will only increase the discontent of those who are on the sidelines of economic growth, thus generating sociopolitical destabilization.

In this article, we identify to what extent the positive correlation between per capita GDP and the level of socio-economic destabilization observed for low and middle income countries can be explained by the fact that economic development there (as was suggested by Kuznets [1955]) is accompanied by an increase in economic inequality.

The hypothesis that the positive correlation between per capita GDP and the level of socio-economic destabilization observed for low and middle income countries is explained by the fact that economic development is accompanied by an increase in economic inequality, when operationalized, may be split into two sub-hypotheses:

(1) There is a statistically significant positive correlation between economic inequality $^{4}$ and the level of socio-political destabilization ${ }^{5}$ (and as we will see below, this statement still has the status of a hypothesis not supported by many empirical tests).

(2) For low and middle income countries, there is a positive correlation between the level of economic development and the level of economic inequality in these countries.

This paper identifies to what extent the positive correlation between the average per capita income level and socio-political instability observed for low and middle income countries can be explained by the growing economic inequality that accompanies economic growth in modernizing societies. To do this, we conduct our own empirical testing of both the above sub-hypotheses. In addition, we identify the contribution that growth in economic inequality accompanying the economic growth in modernizing systems can make to the formation of an inverted U-shaped relationship between GDP per capita and socio-political destabilization.

Our study begins with the first hypothesis test.

\section{Tests}

\section{Economic inequality and socio-political instability}

The thesis that the growth of economic inequality leads to an increase in political instability has not received unequivocal support. Numerous empirical studies of the relationship between the level of economic inequality and socio-political destabilization carried out over the past 45 years, have produced contradictory results. Some researchers conclude that the increase in inequality leads to an increase in sociopolitical instability; others that the relationship between these variables is negative (i.e., the higher the level of

\footnotetext{
4. In our study, we measure it using the Gini coefficient. lars.

5. In our study, we measure it using GDP per capita at PPP calculated at 2011 constant international dol-

6. See, for example: Russett, 1964; Feierabend, Feierabend, 1966; Russo, 1968; Paranzino, 1972; Sigelman, Simpson, 1977; Muller, 1988; Muller, Seligson, 1987; Midlarsky, 1988; Moaddel, 1994; Perotti, 1996; Schock, 1996; Temple, 1998; MacCulloch, 2005; Lempert, 2016; Alexander, 2016, 2017.
} 
economic inequality, the higher the level of political stability) ${ }^{7}$. Further, some researchers conclude that there is a curvilinear relationship between inequality and instability ${ }^{8}$. And, finally, a large number of researchers have concluded that economic inequality does not have any statistically significant effect on the level of socio-political instability ${ }^{9}$. It should be noted that in all cases where some statistically significant relationship between the variables in question still is identified, it usually turns out to be quite weak.

Let us analyze these results in more detail.

We start with those researchers concluding that the growth of economic inequality leads to socio-political destabilization, i.e. those who find a positive relationship between economic inequality and political instability. In the opinion of some of them, countries with a high level of inequality are characterized by the following:

(1) The poor can use force to achieve the requirements of a fair redistribution of income and property.

(2) The rich possess the resources necessary to use force to avoid the implementation of these requirements.

(3) The size of the middle class is extremely small ${ }^{10}$.

From this it follows that socio-political instability must grow with the growth of economic inequality. A number of researchers have found empirical evidence in support of this hypothesis ${ }^{11}$.

Analyzing statistical data for 41 countries from 1945 to 1961, Russett (1964) shows that in poor, predominantly agricultural countries, a high degree of inequality in the land distribution tends to lead to political instability. Similar conclusions are reached by Tanter and Midlarsky (1967) based on the analysis of data for 52 countries from 1955 to 1960.

Inequality in the possession of property and/or means of production (especially land) and income inequality, although correlated, are still essentially different types of inequality, which can explain to some extent the differences in conclusions reached by different researchers. It is also important that inequality in the former case is more difficult to reduce, especially given the much more limited amount of land resources in the country (which is often constant) compared to income (which tends to grow). The problem of inequality in land ownership in poor countries can also be related to the ideological and institutional features of society. An example of pre-revolutionary Russia where the majority of peasants considered private ownership of land unjust ("the land is God's") and

7. See, for example: Mitchell, 1968; Nisbet, 1968; Parvin, 1973; Moore, 1978; Nel, 2003; Elkanj, Gangopadhyay, 2014.

8. See, for example: Davis, 1959; Galtung, 1964; Feierabend, Feierabend, 1966; Nagel, 1974; Hey, Lambert, 1980; Berrebi, Silber, 1985; Gurr, 2015; Boudon, 2016, etc.

9. See, for example: Russo, 1968; Parvin, 1973; Duff, McCamant, Morales, 1976; Hardy, 1979; Weede, 1981; Bingham, 1982; Weede, 1987; Collier, Hoeffler, 1998, 2004; Collier, 2000; Nel, 2003; McAdam, 2010; Østby, Urdal, 2010; Buhaug et al. 2011, etc.

10. See, for example: Russett, 1964; Tanter, Midlarsky, 1967; Prosterman, 1976; Sigelman, Simpson, 1977, etc.

11. See, for example: Russett, 1964; Tanter, Midlarsky 1967; Gurr, 1968; Mitchell, 1969; Paranzino, 1972; Gurr, Duvall, 1973; Morgan, Clark, 1973; Prosterman, 1976; Sigelman, Simpson, 1977; Gurr, Lichbach, 1979; Singer, Wallace, 1979; Muller, Seligson, 1987; Dutt, Mitra, 2008; Nepal, Bohara, Gawande, 2011, etc. 
where communal forms of regular land redistribution prevailed, is quite relevant here. In a number of societies social status is very strongly correlated with property ownership (especially land). For example, in India, land owners were mostly representatives of higher castes or subgroups, and even now this situation is still largely preserved (see, for example, Alaev, 2000).

A large number of researchers have discovered the presence of a statistically significant (although, as a rule, rather weak) correlation between income inequality and sociopolitical instability. Sigelman and Simpson (1977) using cross-national data for 49 countries from 1958 to 1966 about the income inequality of the population, found a moderate $\left(R^{2}=0.311\right)$ statistically significant linear relationship between inequality and political violence.

Dutt and Mitra (2008) find that inequality has a weak $\left(R^{2}=0.11\right)$ positive but significant correlation with the indicators of political instability on the basis of data on 99 countries from 1960 to 2000 . However, according to them, other factors, both political and economic, may strengthen the effect of the economic inequality factor (Dutt, Mitra, 2008).

Somewhat apart is the study of Nepal, Bohara and Gawande (2011) in which, not countries, but Nepalese villages are regarded as units of comparison. The authors test the hypothesis that inequality generates political violence using data on political violence by the Nepalese Maoists in the protracted war they waged against their government. Inequality is measured by the Gini index as well as by polarization indices. The dependent variable is the number of people killed by Maoist insurgents between 1996 and 2003 in each of 3,857 Nepalese villages, for which the authors obtained data. The authors show that a higher level of inequality correlates positively with higher levels of political violence. In their view, the availability of social networks and government social security programs can lead to a reduction in violence, and that higher average incomes can reduce the impact of inequality on conflict (Nepal, Bohara, Gawande, 2011).

Statistically significant positive correlations between economic inequality and sociopolitical instability have been found by a number of other researchers (see, for example, Gurr, 1968; Mitchell, 1969; Paranzino, 1972; Gurr, Duvall, 1973; Morgan, Clark, 1973; Prosterman, 1976; Gurr, Lichbach, 1979; Singer, Wallace, 1979; Muller, Seligson, 1987, etc.).

Other researchers come to the opposite conclusion, finding a negative relationship between economic inequality and political instability. Theoretical expectations are formulated by Moore (1978) as follows: a high level of economic inequality means the presence of a strong elite which has enough resources to suppress political dissent, retain or strengthen its position and thus ensure a high level of political stability (Moore, 1978). A number of empirical tests have confirmed the existence of such a negative relationship between the level of economic inequality and political instability (see, for example: Mitchell, 1968; Nisbet, 1968; Parvin 1973; Moore 1978; Nel 2003; Elkanj, Gangopadhyay, 2014).

The third type of conclusions obtained by researchers looks quite logical: lower economic inequality (in accordance with the theoretical expectations of the first group of 
researchers described above) and the subsequent growth of economic inequality is accompanied by an increase in political instability, and further growth of inequality leads to an increase in political stability. As a result, the general form of the relationship between the degree of economic inequality and political instability is an inverted U-shape, when especially high values of socio-political destabilization tend to be observed at the intermediate values of economic inequality.

According to Nagel (1974), political violence will occur most often at the intermediate level of economic inequality, and less often at very low or very high levels. While "resentment as a result of comparisons" grow, the "tendency to compare" decreases with the level of economic inequality. Given these assumptions, Nagel shows that the resulting cumulative effects result in an inverted $\mathrm{U}$-shaped relationship between economic inequality and sociopolitical destabilization (Nagel, 1974). Similar results are obtained by a number of other researchers (Galtung, 1964, Feierabend, Feierabend, 1966, Nagel, 1974; Hey, Lambert, 1980; Berrebi, Silber, 1985; Boudon, 2016).

Finally, there are studies showing that economic inequality generally has no statistically significant effect on political instability. Collier and Hoeffler (Collier, Hoeffler, 1998, 2004; Collier et al. 2000) analyze internal conflicts using a large set of data on civil wars from 1965 to 1999. They find that inequality and a lack of democracy have no significant influence on the risk of civil war, which is classified in their analysis as an internal conflict with at least 1,00o deaths in clashes and battles. On the other hand, countries characterized by geographical disunity and dominant ethnic or religious groups, or having a significant share of their income (GDP) from commodity exports, are significantly more prone to conflict (note however, that the latter finding has been convincingly rejected by Smith who shows that "oil wealth is robustly associated with increased regime durability, even when controlling for repression, and with lower likelihoods of civil war and antistate protest" [Smith, 2004: 232]).

$\mathrm{Nel}$ (2003) uses household expenditure data to assess the impact of inequality on political instability in sub-Saharan Africa between 1986 and 1997. The analysis shows that a high level of inequality does not affect political instability in a statistically significant way for the sample. Similar results were obtained by many other researchers (see, for example: Russo, 1968; Parvin, 1973; Duff, McCamant, Morales, 1976; Hardy, 1979; Weede, 1981; Bingham, 1982; Weede, 1987; McAdam, 2010; Østby, Urdal, 2010; Buhaug et al., 2011).

Table 1 gives a summary of some results obtained by various researchers as regards the impact of economic inequality on sociopolitical instability.

Table 1. Summary of the results of the empirical tests of the correlation between economic inequality and political instability

\begin{tabular}{|l|l|l|l|l|}
\hline Research ID & Method & $\begin{array}{l}\text { Period } \\
\text { studied }\end{array}$ & Sample size & Categorization of results \\
\hline Russett, 1964 & OLS-regression & $1945-1961$ & 41 countries & $\begin{array}{l}\text { 1. Economic inequality } \\
\text { increases political instability }\end{array}$ \\
\hline Tanter, 1967 & OLS-regression & $1955-1960$ & 52 countries & $\begin{array}{l}\text { 1. Economic inequality } \\
\text { increases political instability }\end{array}$ \\
\hline
\end{tabular}




\begin{tabular}{|c|c|c|c|c|}
\hline Research ID & Method & \begin{tabular}{|l|}
$\begin{array}{l}\text { Period } \\
\text { studied }\end{array}$ \\
\end{tabular} & Sample size & Categorization of results \\
\hline $\begin{array}{l}\text { Morgan, Clark, } \\
1973\end{array}$ & OLS-regression & $1961-1968$ & 30 countries & $\begin{array}{l}\text { 1. Economic inequality } \\
\text { increases political instability }\end{array}$ \\
\hline Barrows, 1976 & OLS-regression & $1963-1968$ & $\begin{array}{l}32 \text { African } \\
\text { countries }\end{array}$ & $\begin{array}{l}\text { 1. Economic inequality } \\
\text { increases political instability }\end{array}$ \\
\hline \begin{tabular}{|l|} 
Sigelman, \\
Simpson, 1977 \\
\end{tabular} & OLS-regression & $1958-1966$ & 49 countries & $\begin{array}{l}\text { 1. Economic inequality } \\
\text { increases political instability }\end{array}$ \\
\hline $\begin{array}{l}\text { Dutt, Mitra, } \\
2008\end{array}$ & OLS-regression & $1960-2000$ & 99 countries & $\begin{array}{l}\text { 1. Economic inequality } \\
\text { increases political instability }\end{array}$ \\
\hline $\begin{array}{l}\text { Nepal, Bohara, } \\
\text { Gawande, } 2011\end{array}$ & $\begin{array}{l}\text { A two-level } \\
\text { hierarchical } \\
\text { model with } \\
\text { negative } \\
\text { binomial } \\
\text { distribution } \\
\end{array}$ & 1996-2003 & $\begin{array}{l}3857 \text { Nepalese } \\
\text { villages }\end{array}$ & $\begin{array}{l}\text { 1. Economic inequality } \\
\text { increases political instability }\end{array}$ \\
\hline $\begin{array}{l}\text { Muller, } \\
\text { Seligson, } 1987\end{array}$ & $\begin{array}{l}\text { Multiple } \\
\text { regression }\end{array}$ & 1973-1977 & 62 countries & $\begin{array}{l}\text { 1. Economic inequality } \\
\text { increases political instability }\end{array}$ \\
\hline Muller, 1988 & OLS-regression & $1965-1975$ & 55 countries & $\begin{array}{l}\text { 2. Curvilinear dependence } \\
\text { between economic inequality } \\
\text { and political instability }\end{array}$ \\
\hline \begin{tabular}{|l|} 
Parvin, 1973 \\
\end{tabular} & OLS-regression & & 26 countries & $\begin{array}{l}\text { 3. Economic inequality } \\
\text { reduces political instability }\end{array}$ \\
\hline $\begin{array}{l}\text { Elkanj, Gango- } \\
\text { padhyay, 2014 }\end{array}$ & OLS-regression & 1963-1999 & $\begin{array}{l}\text { 10 Middle East } \\
\text { countries }\end{array}$ & $\begin{array}{l}\text { 3. Economic inequality } \\
\text { reduces political instability }\end{array}$ \\
\hline Yitzhaki, 1979 & $\begin{array}{l}\text { Basic integral } \\
\text { equations }\end{array}$ & & & $\begin{array}{l}\text { 4. U-shaped relationship } \\
\text { between economic inequality } \\
\text { and political instability }\end{array}$ \\
\hline Giskemo, 2008 & OLS-regression & $1950-2004$ & 188 countries & $\begin{array}{l}\text { 4. U-shaped relationship } \\
\text { between economic inequality } \\
\text { and political instability }\end{array}$ \\
\hline Østby, 2008 & OLS-regression & $1986-2004$ & $\begin{array}{l}36 \text { developing } \\
\text { countries }\end{array}$ & $\begin{array}{l}\text { 4. U-shaped relationship } \\
\text { between economic inequality } \\
\text { and political instability }\end{array}$ \\
\hline Nagel, 1974 & OLS-regression & $1961-1965$ & 51 countries & $\begin{array}{l}\text { 5. Inverted U-shaped } \\
\text { relationship between } \\
\text { economic inequality and } \\
\text { political instability }\end{array}$ \\
\hline $\begin{array}{l}\text { Collier, Hoeffler, } \\
1998\end{array}$ & Probit analysis & $1960-1962$ & 100 countries & $\begin{array}{l}\text { 6. Inequality has no } \\
\text { significant correlation with } \\
\text { political instability }\end{array}$ \\
\hline $\begin{array}{l}\text { Fearon, Laitin, } \\
2003\end{array}$ & $\begin{array}{l}\text { Poisson } \\
\text { regression, } \\
\text { logit analysis } \\
\end{array}$ & $1945-1949$ & 156 countries & $\begin{array}{l}\text { 6. Inequality has no } \\
\text { significant correlation with } \\
\text { political instability }\end{array}$ \\
\hline $\mathrm{Nel}, 2003$ & OLS-regression & 1986-1997 & $\begin{array}{l}\text { Sub-Saharan } \\
\text { Africa }\end{array}$ & $\begin{array}{l}\text { 6. Inequality has no } \\
\text { significant correlation with } \\
\text { political instability }\end{array}$ \\
\hline $\begin{array}{l}\text { Collier, Hoeffler, } \\
2004\end{array}$ & OLS-regression & $1960-1999$ & 161 countries & $\begin{array}{l}\text { 6. Inequality has no } \\
\text { significant correlation with } \\
\text { political instability }\end{array}$ \\
\hline
\end{tabular}


Table 2 give the results of our own tests for the correlation between the level of economic inequality measured with the Gini coefficient and Cross-National Time Series / CNTS database ${ }^{12}$ indices of socio-political destabilization (Banks, Wilson, 2017).

Table 2. Correlations between the level of inequality and CNTS socio-political destabilization indicators for 1960-2014

\begin{tabular}{|c|l|c|c|}
\hline № & Subcategory & $\begin{array}{c}\text { Statistical } \\
\text { significance }(\boldsymbol{p})\end{array}$ & $\begin{array}{c}\text { Pearson's correlation } \\
\text { coefficient }(\boldsymbol{r})\end{array}$ \\
\hline 1 & Assassinations & $<0.001$ & 0.146 \\
\hline 2 & General strikes & 0.033 & 0.061 \\
\hline 3 & Guerrilla warfare & $<0.001$ & 0.129 \\
\hline 4 & Government crises & 0.014 & 0.070 \\
\hline 5 & Purges & 0.159 & -0.040 \\
\hline 6 & Riots & 0.749 & -0.009 \\
\hline 7 & "Revolutions"13 & $<0.001$ & 0.111 \\
\hline 8 & Anti-government demonstrations & 0.012 & 0.072 \\
\hline 9 & Integral sociopolitical destabilization index & $<0.001$ & 0.170 \\
\hline
\end{tabular}

Data sources: Banks, Wilson, 2017; World Bank, 2017.

In seven of the nine tests we find statistically significant correlations in the predicted direction, generally supporting the hypothesis that the growth of economic inequality tends to lead to an increase in political instability. On the other hand, we are talking about statistically significant, but extremely weak correlations. Indeed, the strongest correlation in our case is observed between the Gini index of economic inequality and the integral CNTS index of socio-political destabilization ${ }^{14}$. The strength of this correlation measured by the Pearson coefficient $(r)$, is 0.170 , which corresponds to the coefficient of determination $\left(R^{2}\right)$ of 0.0289 . Thus, in this test, economic inequality determines the level of socio-political instability by less than $3 \%$. Consequently, economic inequality is an extremely weak predictor of sociopolitical destabilization, which a number of authors have pointed out.

Nevertheless, the correlations between the index of economic inequality and some indices of socio-political destabilization are quite strong when we take as a unit of analysis not individual country-years ${ }^{15}$, but deciles.

12. See appendix to this article for its description.

13. One should keep in mind that the name of this variable given by the CNTS developers ("Revolutions" [see, for example: Wilson, 2017: 13]) misleads the user to a very significant degree, since in reality it describes in most cases not revolutions in the academic sense (for our summary of the definitions of the revolution see, for example, Grinin, Issaev, Korotayev, 2015), but rather coups and coups attempts.

14. See appendix to this article for a description of the methodology for calculating this index.

15. The unit of description in our databases is, strictly speaking, not an individual country, but a countryyear, i.e. we are talking about the characteristics of a country for a certain year - for example, about the number of anti-government demonstrations in Indonesia in 1997 or the Us Gini economic inequality index in 2007 . 
It is worth considering some specific cases of correlation between the level of economic inequality and the intensity of several types of socio-political destabilization. In the following series of tests, we deal with mean values of indices of socio-political destabilization for deciles of country-years as regards the Gini index of economic inequality. For example, the leftmost marker in Fig. 1 denoted by the black square corresponds to $10 \%$ of the country-years with the lowest level of socio-economic inequality, the neighboring marker corresponds to the next $10 \%$, and the rightmost upper marker corresponds to $10 \%$ of the country-years with the highest level of economic inequality.

In Fig. 1 for $10 \%$ of country-years with the lowest level of economic inequality, the average value of the intensity of political assassinations is 0.009, i.e. there are 9 political assassinations per 1000 country-years or less than one political assassination in a century, and for $10 \%$ of the country-years with the highest level of economic inequality, the average value of the intensity of political assassinations is 0.669 , i.e. for 1,00o country-years, there are 669 political assassinations, that is. 2 political assassinations every 3 years). In general, the per decile analysis shows that the highest correlation with economic inequality is found precisely for the intensity of political assassinations (see Figure 1).

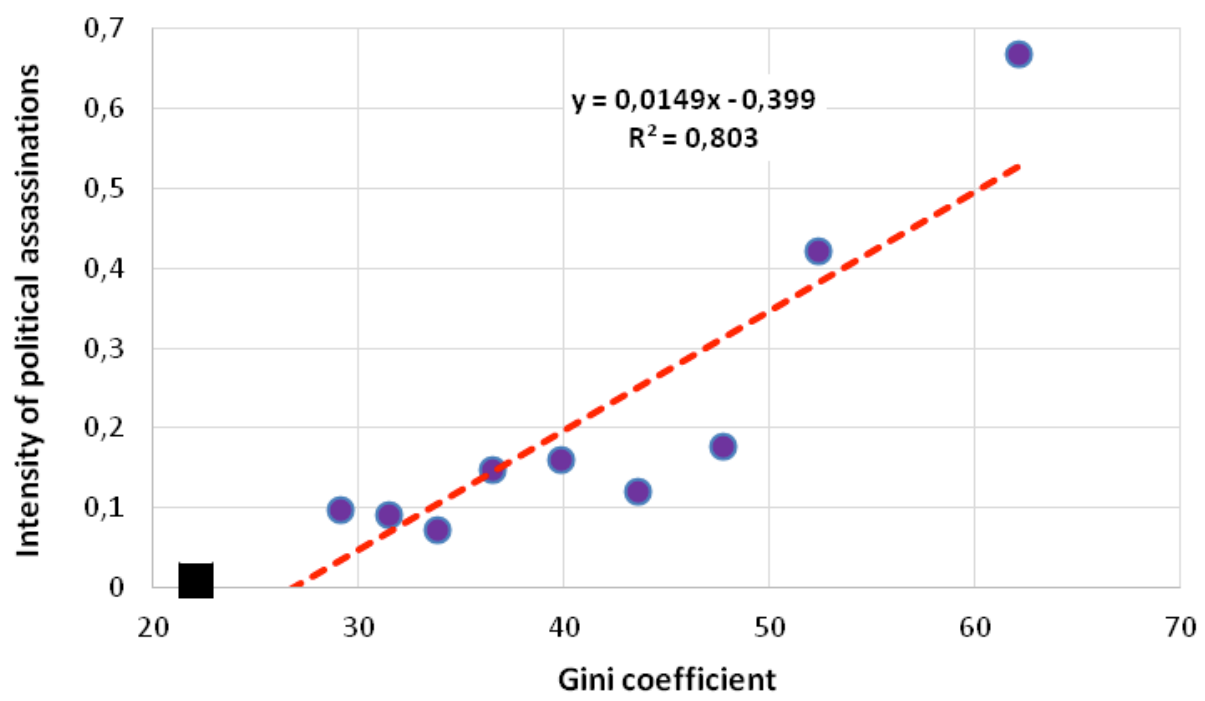

Data source: Banks, Wilson 2017; World Bank 2017.

Note: $r=0,896, p=0.0004$. In this and the following four cases, the following decile boundaries were used: the 1st decile: $<27$; the 2 nd decile: $27-30$; the 3rd decile: $30-32$; the 4 th decile: $32-34$; the 5 th decile: $34-38$; the 6 th decile: $38-41$; the 7 th decile: the $41-45$; the 8 th decile: $45-49$; the 9 th decile: $49-54$; the 1oth decile: $>54$. It is worth recalling that the unit of observation in our calculations is not a particular country, but, strictly speaking, a country-year, i.e., country $X$ in year $Y$.

Figure 1. Per decile correlation between economic inequality and the intensity of political assassinations, 1960-2014

(scatterplot with a fitted regression line) 
The per decile analysis suggests that the correlation between economic inequality and the intensity of political assassinations is very strong $\left(r=0.896, R^{2}=0.803\right)$ and statistically significant beyond any doubt $(p=0.0004)$. Note the particularly significant leap in the intensity of political assassinations is observed when the value of the Gini index exceeds a threshold level of about 50 points (which corresponds to the border between the $8^{\text {th }}$ and $9^{\text {th }}$ deciles).

The per decile analysis also finds a fairly strong correlation between the economic inequality index and the intensity of terrorist acts/guerrilla warfare, shown in Figure 2.

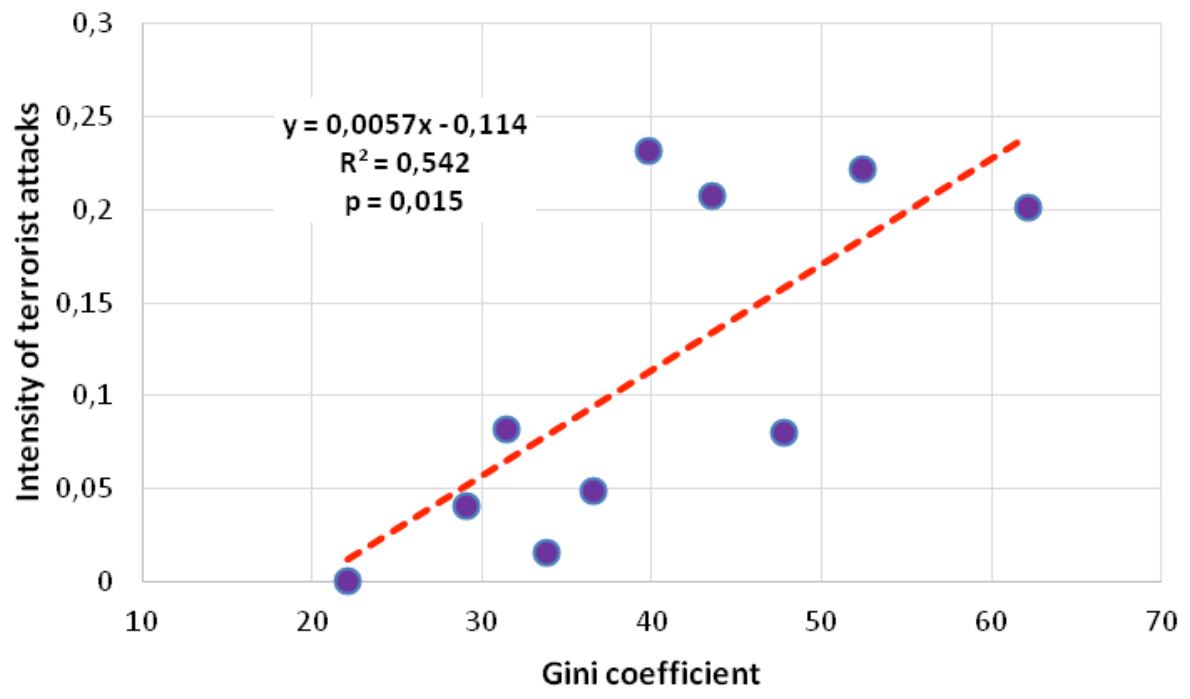

Data source: Banks, Wilson 2017; World Bank 2017.

Note: $r=0.736, p=0.015$.

Figure 2. Per decile correlation between economic inequality and the intensity of major terrorist attacks/guerrilla warfare, 1960-2014 (scatterplot with a fitted regression line)

In this case we are dealing with a rather strong $(r=0.736)$ statistically significant ( $p=$ o.015) correlation. The threshold value of the Gini index (at which there is a leap in the intensity of terrorist acts/guerrilla warfare) is observed at a threshold level of about 40 points (which corresponds to the area of the $6^{\text {th }}$ decile).

The per decile analysis also reveals a marginally significant but still quite strong positive correlation between the Gini index and the intensity of anti-government demonstrations, shown in Figure 3. Here the threshold value of the Gini index (at which we see a leap in the intensity of anti-government demonstrations) is also observed at a level of about 40 points. 


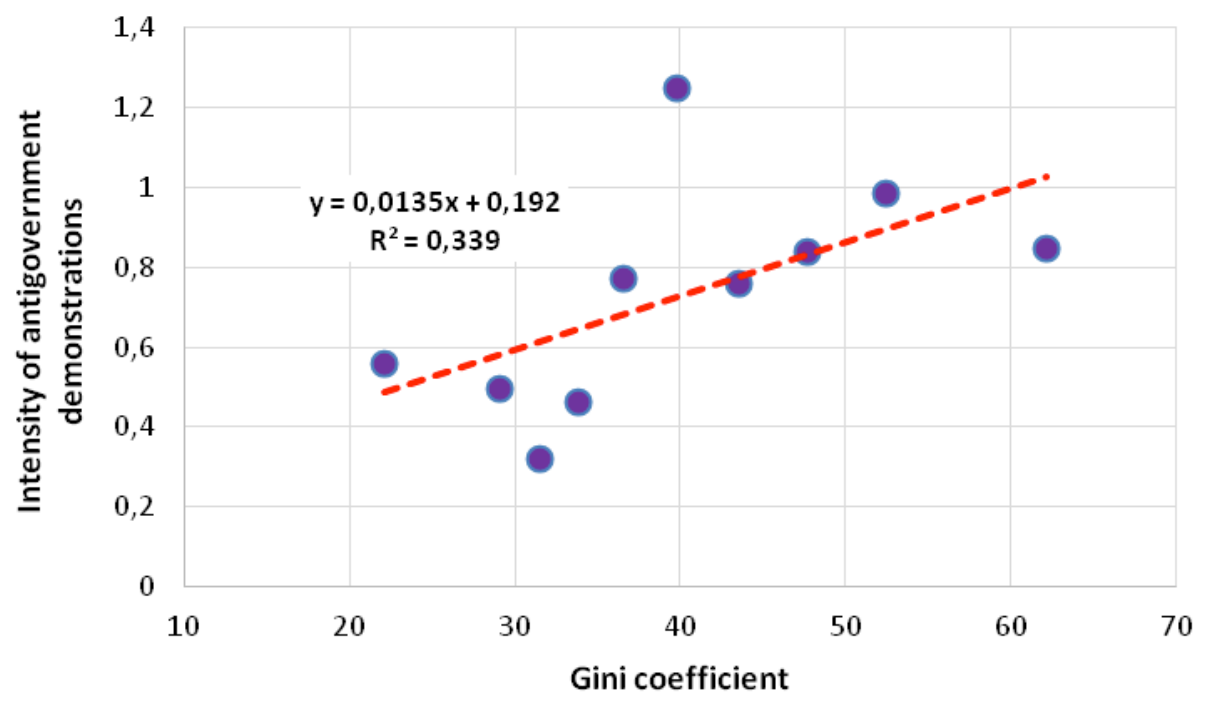

Data source: Banks, Wilson, 2017; World Bank, 2017.

Note: $r=0.582, p=0.039$ (1-tailed).

Figure 3. Per decile correlation between economic inequality and the intensity of anti-government demonstrations, 1960-2014 (scatterplot with a fitted regression line)

The per decile analysis also reveals a sufficiently strong statistically significant correlation with respect to the integral CNTS index of sociopolitical destabilization, shown in Figure 4. Here the threshold value of the Gini index (at which we see a leap in the values of the CNTS integral index of socio-political destabilization) is also observed at the level of about 40 points.

Particularly noteworthy is the fact that for the period after the end of the Cold War, there is a particularly strong correlation between the Gini economic inequality coefficient and the overall level of socio-political destabilization, shown in Figure 5.

In the present period economic inequality can be regarded as a stronger factor of socio-political destabilization. We note the presence of a threshold value at the level of about 40 points, around which a marked jump in the general level of sociopolitical instability is observed ${ }^{16}$.

16. Taking this into account, a very practical recommendation appears. To maintain a high level of sociopolitical stability in the country, it is desirable to avoid exceeding the level of economic inequality significantly above 40 points on the Gini scale. Note that according to the World Bank (World Bank, 2017: SI.POV.GINI) this level in Russia (42 points) is just in the "risk zone", when even a small further increase in economic inequality can lead to significant socio-political destabilization. 


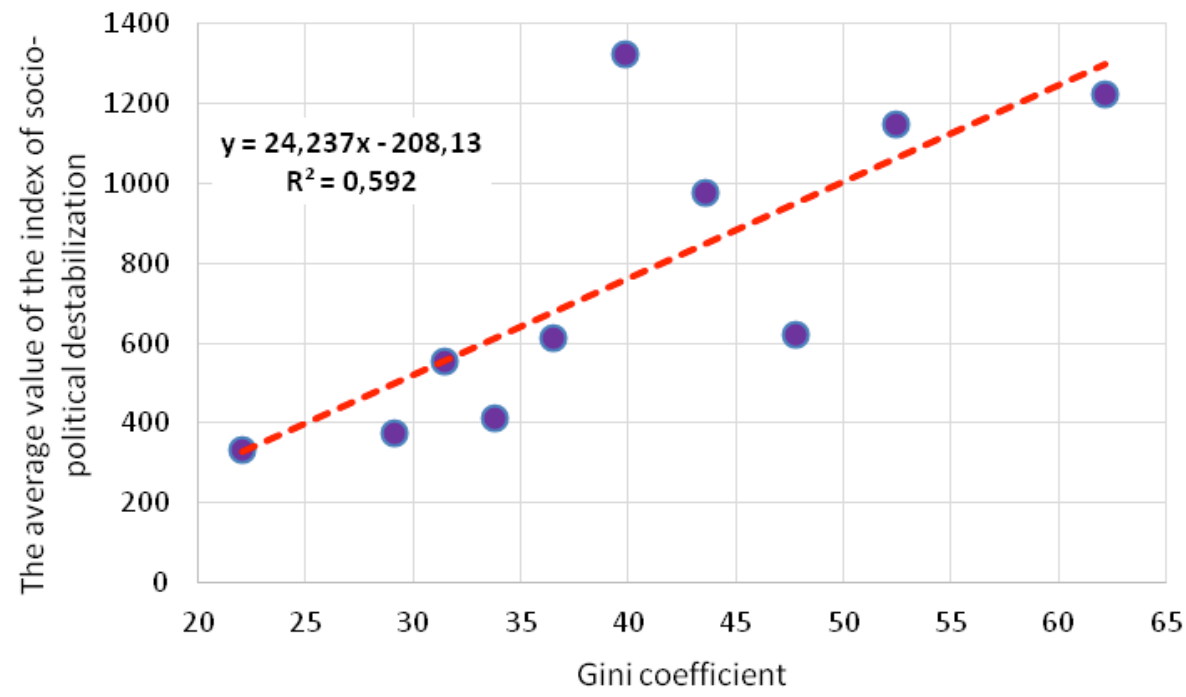

Data source: Banks, Wilson 2017; World Bank 2017.

Note: $r=0.769, p=0.009$.

Figure 4. Per decile correlation between economic inequality and the CNTS integral index of sociopolitical destabilization, 1960-2014 (scatterplot with a fitted regression line)

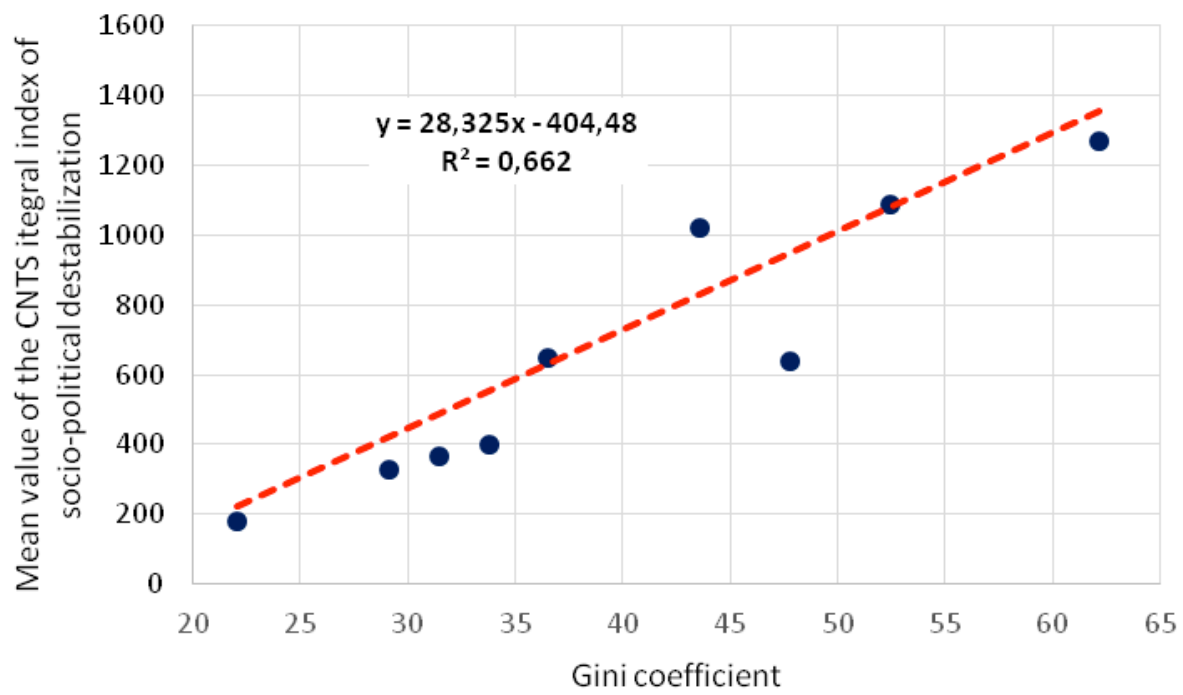

Data source: Banks, Wilson, 2017; World Bank, 2017.

Note: $r=0.813, p=0.004$.

Figure 5. Per decile correlation between economic inequality and the integral CNTS index of sociopolitical destabilization, 1992-2014 (scatterplot with a fitted regression line) 
Thus, there are grounds to assert that economic inequality can serve as a sufficiently serious factor of socio-political destabilization both in general, and in particular with regard to such indicators as anti-government demonstrations, major terrorist attacks/ guerrilla warfare and political assassinations.

It is necessary now to test the second sub-hypothesis, which states that for the low and middle income countries there is a positive correlation between the level of economic development and the level of economic inequality.

\section{Economic development and economic inequality}

We re-test Kuznets' (1955) hypothesis that in the early stages of modernization, economic growth tends to be accompanied by increasing economic inequality, and in the later stages, the opposite correlation is observed. Taking into account the specifics of the database (World Bank, 2017) that is used to re-test the Kuznets theory, this hypothesis is operationalized as follows: for countries with lower per capita GDP values, a positive correlation between GDP per capita and the Gini index is expected, while for richer countries it is negative. The test generally supports Kuznets' hypothesis (see Figures 6-7 and Table 3):

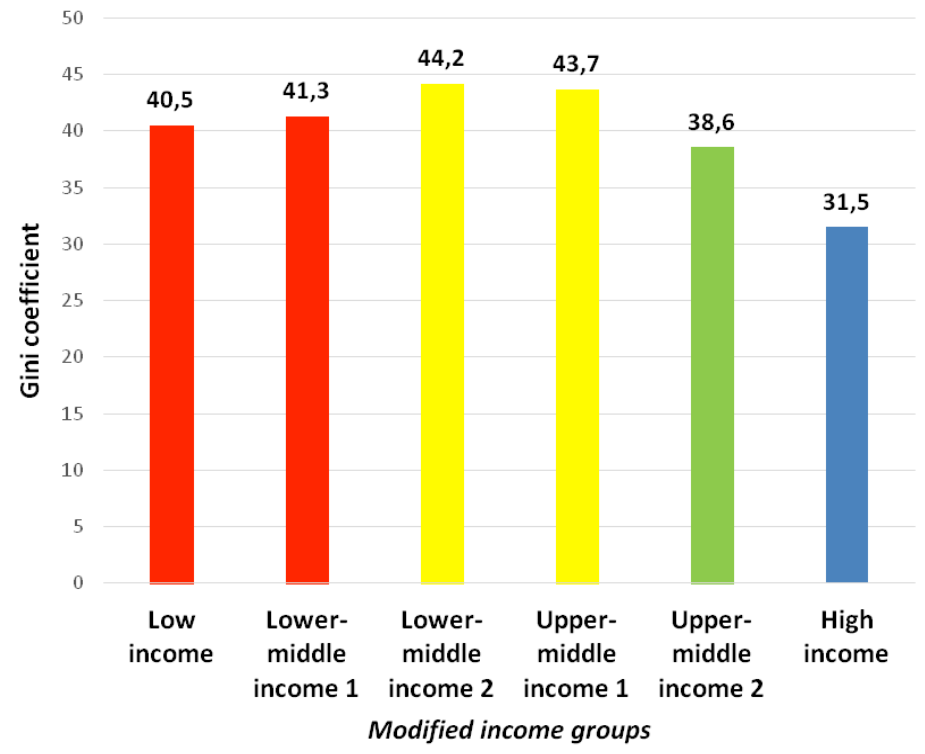

Data source: Banks, Wilson, 2017; World Bank, 2016.

Note: The statistical significance of the differences between the categories (shown in the figures in different colors) is determined here and further with the help of the Dunnett test $(\mathrm{p}<0.05)$ and the one-way ANOVA procedure. $F=61.45, p<<0.0001$.

Figure 6. Mean values of the Gini coefficient for modified World Bank income groups ${ }^{17}, 1960-2014$

17. See appendix to this article for the description and rationale of the modified income group classification that we use. 


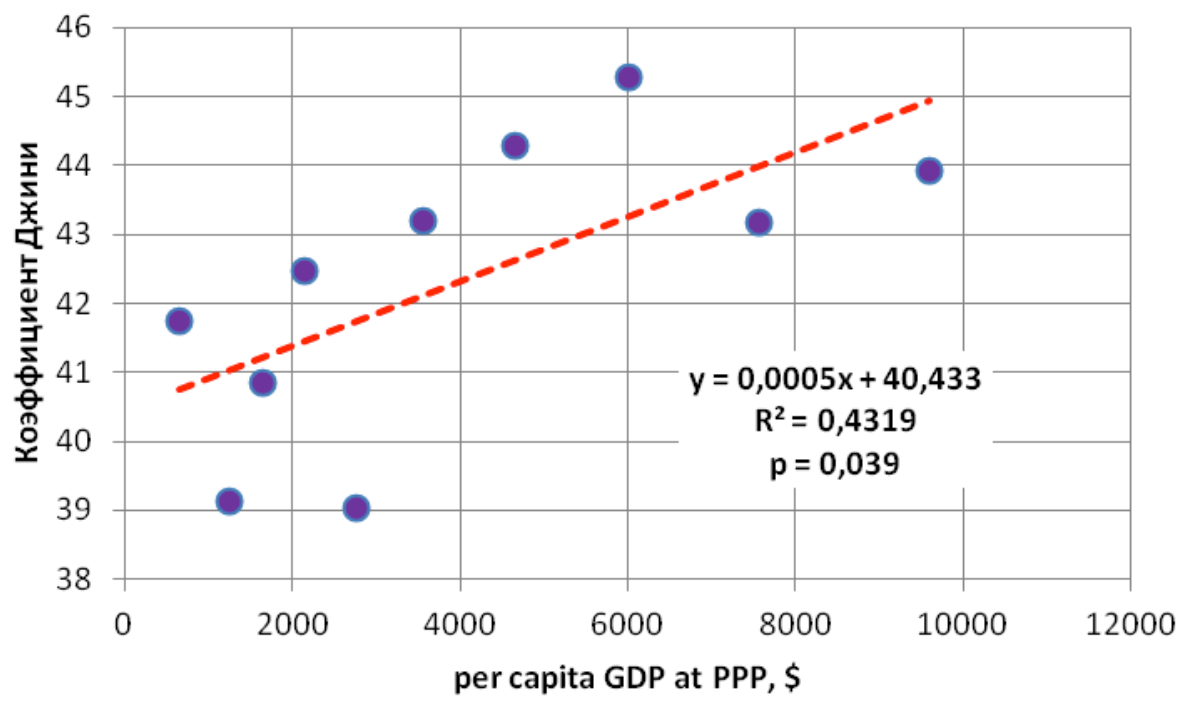

Data source: Banks, Wilson, 2017; World Bank, 2017.

Note. Decile boundaries for this graph are as follows. The 1 st decile: $<\$ 1,052$. The 2 nd decile: $\$ 1,052-1,436$. The 3rd decile: $\$ 1,436-1,848$. The 4 th decile: $\$ 1,848-2,435$. The 5 th decile: $\$ 2,435-3,112$. The 6 th decile: $\$ 3,112-4,011$. 7 th decile: $\$ 4,011-5,305$. The 8 th decile: $\$ 5,305-6,711$. The 9 th decile: $\$ 6,711-8,437$. The 1oth decile: $\$ 8,437-$ 10,745 . It is also important to recall that the unit of observation in our calculations is not a country, but, strictly speaking, a country-year, i.e. country $X$ at year $Y$.

Figure 7. Per decile correlation of per capita GDP with mean levels of economic inequality for countries with income up to $\$ 10,750,1960-2014$ (scatterplot with a fitted regression line)

Table 3. Results of Scheffe's post hoc comparison of the Gini coefficient for the main income groups, 1960-2014

\begin{tabular}{|c|c|c|c|c|}
\hline & & Mean difference & Std. error & p-value \\
\hline \multirow{5}{*}{ Low income } & $\begin{array}{l}\text { Lower-middle } \\
\text { income } 1\end{array}$ & 0.82 & 1.21 & 0.90 \\
\hline & $\begin{array}{l}\text { Lower-middle } \\
\text { income } 2\end{array}$ & 3.71 & 1.13 & $<0.01$ \\
\hline & $\begin{array}{l}\text { Upper-middle } \\
\text { income } 1\end{array}$ & 3.17 & 1.05 & 0.01 \\
\hline & $\begin{array}{l}\text { Upper-middle } \\
\text { income } 2\end{array}$ & -1.94 & 1.08 & 0.21 \\
\hline & High income & -8.99 & 1.09 & $<0.01$ \\
\hline \multirow{4}{*}{$\begin{array}{l}\text { Lower-middle } \\
\text { income } 1\end{array}$} & $\begin{array}{l}\text { Lower-middle } \\
\text { income } 2\end{array}$ & 2.90 & 1.03 & 0.02 \\
\hline & $\begin{array}{c}\text { Upper-middle } \\
\text { income } 1\end{array}$ & 2.36 & 0.94 & 0.04 \\
\hline & $\begin{array}{l}\text { Upper-middle } \\
\text { income } 2\end{array}$ & -2.76 & 0.98 & 0.02 \\
\hline & High income & -9.81 & 0.99 & $<0.01$ \\
\hline
\end{tabular}




\begin{tabular}{|c|c|c|c|c|}
\hline \multirow{2}{*}{$\begin{array}{c}\text { Lower-middle } \\
\text { income 2 }\end{array}$} & $\begin{array}{c}\text { Upper-middle } \\
\text { income 1 }\end{array}$ & -0.54 & 0.83 & 0.84 \\
\cline { 2 - 5 } & $\begin{array}{c}\text { Upper-middle } \\
\text { income 2 }\end{array}$ & -5.66 & 0.87 & $<0.01$ \\
\cline { 2 - 5 } & High income & -12.70 & 0.89 & $<0.01$ \\
\hline $\begin{array}{c}\text { Upper-middle } \\
\text { income 1 }\end{array}$ & $\begin{array}{c}\text { Upper-middle } \\
\text { income 2 }\end{array}$ & -5.12 & 0.73 & $<0.01$ \\
\cline { 2 - 5 } & High income & -12.17 & 0.75 & $<0.01$ \\
\hline $\begin{array}{c}\text { Upper-middle } \\
\text { income 2 }\end{array}$ & High income & -7.05 & 0.64 & $<0.01$ \\
\hline
\end{tabular}

Data source: Banks, Wilson, 2017; World Bank, 2017.

Note: $F=61.45, p<<0.0001$.

Figs. 6-7 and Table 3 show that in our database covering the countries of the world, 1960-2014, a statistically significant correlation between the level of per capita GDP and the level of economic inequality (measured with the Gini coefficient) is observed, but within a rather limited interval: up to the level of $\$ 5,500-6,500$. However, starting from the level of $\$ 6,500-12,000$, a pronounced negative correlation between per capita GDP and the level of economic inequality begins. The negative correlation between GDP per capita and economic inequality in the right part of the spectrum of per capita GDP values is much more pronounced than the positive correlation in the left part of the spectrum.

Although the mean Gini index in the upper echelon of lower-middle income countries (44.25) is not much higher than its mean value for low income countries (40.5), this difference is statistically significant and is in the area where we have detected a threshold level at which we observe a leap in the value of the integral CNTS index of socio-political destabilization, as well as in the values of such important indicators as the intensity of major terrorist attacks/guerrilla warfare and anti-government demonstrations, which indicates that a rise in inequality in the low and middle income countries could have a powerful destabilizing effect.

\section{Discussion and conclusion}

The results show that, as Olson and Huntington suggested, the growth of economic inequality along with economic development in low and middle income countries can be considered as mechanisms that can partly explain the positive correlation between per capita incomes and levels of socio-political destabilization. At the same time, these results show the limits of this explanation.

First, for these countries we find a statistically significant, but not very strong $(r=$ +0.657 ) positive correlation between GDP per capita and the level of economic inequality. Earlier we found much stronger positive correlations for the same countries for some of the most important components of socio-political destabilization (see Korotayev et al., 2016: Chapter 2). The Pearson per decile correlation coefficient $(r)$ for the intensity of political assassinations is +0.881 , for political strikes it is +0.930 , and for anti-government 
demonstrations it is +0.941. The tendency toward an increase in the intensity of political assassinations, strikes and anti-government demonstrations with GDP per capita growth which is very pronounced among low and middle income countries, can be explained only partially with the help of the much less pronounced tendency toward the increase in economic inequality with per capita GDP growth which we observe among these countries.

Second, the positive correlation between per capita GDP and economic inequality can be traced only within a limited interval (up to $\sim \$ 5,500-6,500$ ). For a number of important components of socio-political destabilization, this correlation can be traced for much broader ranges of GDP per capita: for political strikes it is found up to $\sim \$ 10,300-$ 14,500 , and for mass riots and anti-government demonstrations it is found up to \$14,500-20,000 (see Korotayev et al., 2016: Chapter 2). The growth of economic inequality cannot explain the pronounced tendency toward an increase in the intensity of antigovernment demonstrations and riots with the growth of per capita GDP in the range between $\$ 6,500$ and $\$ 20,000$ (which we observe in our database) for the simple reason that in this database we do not find in this range a positive correlation between per capita GDP and economic inequality (i.e., higher income countries in this range do not tend to have higher levels of economic inequality). However, for the range from the minimum up to $\$ 6,500$ the increase in economic inequality can certainly be used to partly explain the positive correlation between GDP per capita and the level of sociopolitical instability.

And a final remark. Our empirical results show a threshold value at about 40 points on the Gini index of economic inequality, after which we observe a tendency toward an abrupt increase in the sociopolitical instability as a whole, and the intensity of terrorist attacks/guerrilla warfare and anti-government demonstrations in particular. Russia by this indicator is located precisely in this zone (World Bank, 2017), which suggests that further growth of economic inequality may lead to an abrupt growth of political instability.

\section{Appendix: Methods and Materials}

\section{Cross-National Time Series (CNTS)}

The Cross-National Time Series (CNTS) database is a data compilation and systematization started by Arthur Banks (Banks \& Wilson, 2015) in 1968 at the State University of New York, Binghamton. The work is based on generalizing the archive of data from The Statesman's Yearbooks, published since 1864. It also contains approximately 200 indicators for more than 200 countries. The database contains yearly values of indicators starting from 1815 excluding the periods of World Wars I and II (1914-1918 and 1939-1945).

CNTS database is structured by sections, such as territory and population, technology, economic and electoral data, internal conflicts, energy use, industry, military expenditures, international trade, urbanization, education, employment, legislative activity. 
In our paper we use the data describing internal conflicts (domestic). This section includes data starting from 1919 based on the analysis of events in 8 various subcategories, which are used to compile Integral Index of Sociopolitical Destabilization (domestic9). When calculating the Integral Index, the developers of CNTS database give each category a certain weight (see Table A1).

Table A1. Weights of subcategories used in calculating the Integral Index of Sociopolitical Destabilization

\begin{tabular}{|c|c|c|}
\hline Subcategory & Variable name & $\begin{array}{c}\text { Weight within the Integral Index } \\
\text { of Sociopolitical Destabilization (domestic9) }\end{array}$ \\
\hline Assassinations & domestic1 & 25 \\
\hline General Strikes & domestic2 & 20 \\
\hline Guerrilla Warfare & domestic3 & 100 \\
\hline Government Crises & domestic4 & 20 \\
\hline Purges & domestic5 & 20 \\
\hline Riots & domestic6 & 25 \\
\hline Revolutions & domestic7 & 150 \\
\hline $\begin{array}{c}\text { Anti-Government } \\
\text { Demonstrations }\end{array}$ & domestic8 & 10 \\
\hline
\end{tabular}

To calculate the Integral Index of Sociopolitical Destabilization (Weighted Conflict Measure, domestic9) the numerical values of each subcategory are multiplied by their corresponding weights, the results of the multiplications are summed up, then the sum is multiplied by 100 and divided by $8-$ see formula (1):

(1) domestic9 $=\frac{\begin{array}{l}25 \text { domestic } 1+20 \text { domestic } 2+100 \text { domestic } 3+20 \text { domestic4 }+ \\ 20 \text { domes } 5+25 \text { domestic } 6+150 \text { domestic }+10 \text { domestic } 8\end{array}}{8} \times 100^{18}$

\section{A new classification of income groups: description and rationale}

Yearly GDP per capita (2011 international \$, PPP) were used for the World Bank World Development Indicators database (World Bank, 2016a).

For restoring data from 1960 until 1990, the index of GDP per capita was used (World Bank, 2016b). For testing hypotheses, data from 1960 until 2015 were used.

18. An anonymous referee raises concerns that we study correlations between interval variables (such as per capita GDP and Gini coefficient), on the one hand, and various measures of sociopolitical destabilizations that she or he considers ordinal, or even nominal (qualitative), which might stipulate the use of special statistical techniques. In fact, the CNTS measures of sociopolitical destabilizations are strictly interval. For example, variable domestic8 denotes just the number of anti-government demonstrations recorded in a particular country in a particular year, and thus should be regarded as a squarely interval variable. The same can be said about the CNTS integral index of sociopolitical destabilization (domestic9) that is calculated with a mathematical equation using interval variables only. 
Groups of countries by income were aggregated by GDP per capita (PPP) values (based on an optimization of the World Bank's methodology (World Bank, 2016c, 2016d) to the index).

In the fiscal year 2016, the World Bank distinguished among the following groups of countries by income per capita:

- low income economies/countries - with GNI (gross national income) per capita up to $\$ 1,045^{19}$;

- lower middle income economies/countries - with GNI (gross national income) per capita from $\$ 1,046$ to $\$ 4,125$;

- upper middle income economies/countries - with GNI (gross national income) per capita from $\$ 4,126$ to $\$ 1,735$;

- high income economies/countries - with GNI (gross national income) per capita more than \$12,735 (World Bank, 2016d, 2016e).

However, using this classification in our research was connected with two challenges:

(1) unlike the data on GDP, in the World Bank database there were too many omissions for GNI that cannot be restored (especially for the period before 1980); for this reason, it was more expedient in our case to take as a basis the data not on GNI per capita, but on GDP per capita (that we restored for the overwhelming majority of countries over the whole period between 1960 and 2015);

(2) the division of countries by the World Bank classification is rather uniform. Both high income countries and low income countries contain approximately a billion people each (that corresponds to a notion of the "golden billion" popular in Russia and Collier's "bottom billion" [Collier, 2007]). Middle income countries contain the rest of the world's population - about 5 billion people. This problem was partially solved by the World Bank by dividing middle income countries into two categories: "lower-middle countries" and "upper-middle countries". Even this procedure solved the problem only partially as each of these two categories contains more population than low and high income countries combined.

To solve this problem, we classified the countries (more precisely, "country-years") of the period 1960-2015 into the following sextiles by GDP per capita (2011 international dollars, PPP):

The 1st sextile - up to $\$ 1,660$.

The 2 nd sextile $-\$ 1,660-\$ 3,280$.

The 3 rd sextile $-\$ 3,280-\$ 6470$.

The 4 th sextile $-\$ 6,470-\$ 12,100$.

The 5 th sextile $-\$ 12,100-\$ 23,600$.

The 6 th sextile - from $\$ 23,600$.

In 2014, the correlation between our sextiles and the groups of countries by income according to the World Bank classification was as follows (see. Tab. A2):

19. Note that the calculation is made using a special method, known as the "Atlas method" (for description of the method see: 2016c). 
Table A2. Correlation between two classifications

\begin{tabular}{|c|c|c|c|c|c|c|}
\hline & & \multicolumn{4}{|c|}{$\begin{array}{l}\text { Groups of countries by GNI per capita } \\
\text { distinguished by the World Bank }\end{array}$} & \multirow[b]{2}{*}{ Tota } \\
\hline & & Low income & $\begin{array}{l}\text { Lower- } \\
\text { middle } \\
\text { income }\end{array}$ & $\begin{array}{l}\text { Upper- } \\
\text { middle } \\
\text { income }\end{array}$ & High income & \\
\hline \multirow{6}{*}{$\begin{array}{c}\text { Sextiles of } \\
\text { countries } \\
\text { by GDP per } \\
\text { capita }\end{array}$} & the 1st & 17 & 0 & 0 & o & 17 \\
\hline & the $2 \mathrm{nd}$ & 10 & 15 & 0 & o & 25 \\
\hline & the $3 \mathrm{rd}$ & 0 & 16 & 5 & o & 21 \\
\hline & the 4 th & 0 & 12 & 17 & o & 29 \\
\hline & the 5 th & 0 & 0 & 26 & 10 & 36 \\
\hline & the 6 th & o & o & 3 & 42 & 45 \\
\hline \multicolumn{2}{|c|}{ Total } & 27 & 43 & 51 & 52 & 173 \\
\hline
\end{tabular}

Between the groups of countries by GNI per capita distinguished by the World Bank and our six sextiles of countries by GDP per capita there is a very strong correlation (Spearman's rank correlation coefficient, o.924). In general, all countries of the 1st sextile belong to the group of low income countries by the World Bank classification, the majority of countries of the 2 nd and the 3 rd sextiles belong to the group of lower-middle income countries, the majority of countries of the 4 th and the 5 th sextiles belong to the group of upper-middle income countries, and almost all the countries of the 6th sextile belong to the group of high income countries. This enable us to assign to our sextiles the following notations keeping some appropriate conformity with the World Bank's widely accepted classification of world economies into income groups:

- the 1st sextile = low income countries;

- the and sextile = the lower echelon of lower-middle income countries;

- the 3 rd sextile $=$ the upper echelon of lower-middle income countries;

- the 4 th sextile = the lower echelon of upper-middle income countries;

- the 5 th sextile $=$ the upper echelon of upper-middle income countries;

- the 6 th sextile $=$ high income countries.

\section{References}

Alaev L. (200o) Obshhina v ego zhizni: istorija neskol'kih nauchnyh idej v dokumentah $i$ materialah [The Community in His Life: History of Several Scientific Ideas in Documents and Materials], Moscow: Vostochnaya literatura.

Alexander M. A. (2016) Application of Mathematical Models to English Secular Cycles. Cliodynamics, vol. 7, no 1. Available at: http://escholarship.org/uc/item/230872k1 (accessed 24 March 2017)

Alexander M. A. (2017) Involvement of a Capitalist Crisis in the 1900-30 Inequality Trend Reversal. Cliodynamics, vol. 8, no 1. Available at: http://escholarship.org/uc/ item/42p5m46m (accessed 24 March 2017) 
Banks A. S., Wilson K. A. (2017) Cross-National Time-Series Data Archive. Available at: https://www.cntsdata.com (accessed 24 March 2017).

Berrebi Z. M., Silber J. (1985) Income Inequality Indices and Deprivation: a Generalization. Quarterly Journal of Economics, vol. 100, no 3, pp. 807-810.

Bingham P. G. (1982) Contemporary Democracies: Participation, Stability, and Violence, Harvard: Harvard University Press.

Boudon R. (2016) The Unintended Consequences of Social Action, Berlin: Springer.

Buhaug H., Gleditsch K. S., Holtermann H., Ostby G., Tollefsen A. F. (2011) It's the Local Economy, Stupid! Geographic Wealth Dispersion and Conflict Outbreak Location. Journal of Conflict Resolution, vol. 55, no 5, pp. 814-840.

Chapman T., Reinhardt E. (2013) Global Credit Markets, Political Violence, and Politically Sustainable Risk Premia. International Interactions, vol. 39, no 3, pp. 316-342.

Collier P. et al. (200o) Economic Causes of Civil Conflict and Their Implications for Policy, Washington: World Bank.

Collier P., Hoeffler A. (1998) On Economic Causes of Civil War. Oxford Economic Papers, vol. 50, no 4, pp. 563-573.

Collier P., Hoeffler A. (2004) Greed and Grievance in Civil War. Oxford Economic Papers, vol. 56, no 4, pp. 563-595.

Davies J. A. (1959) A Formal Interpretation of the Theory of Relative Deprivation. Sociometry, vol. 22, no 4, pp. 28o-296.

Davies J. C. (1962) Toward a Theory of Revolution. American Sociological Review, vol. 27, no 1 , pp. 5-19.

DiGiuseppe M. R., Barry C. M., Frank R. W. (2012) Good for the Money: International Finance, State Capacity, and Internal Armed Conflict. Journal of Peace Research, vol. 49, no 3, pp. 391-405.

Duff E. A., McCamant J. F., Morales W. Q. (1976) Violence and Repression in Latin America: a Quantitative and Historical Analysis, New York: Free Press.

Dutt P., Mitra D. (2008) Inequality and the Instability of Polity and Policy. Economic Journal, vol. 118, no 531, 843-860.

Elkanj N., Gangopadhyay P. (2014) Why is the Middle East Burning? An Historical Analysis of the Economic Causes of Conflicts from 1963 to 1999. International Journal of Development and Conflict, vol. 4. no 1, pp. 35-48.

Feierabend I. K., Feierabend R. L. (1966) Aggressive Behaviors Within Polities, 1948-1962: a Cross-National Study. Journal of Conflict Resolution, vol. 10, no 3, pp. 249-271.

Galtung J. (1964) A Structural Theory of Aggression. Journal of Peace Research, vol. 1, no 2, pp. 95-119.

Goldstone J. (2014) Revolutions: A Very Short Introduction, Oxford: Oxford University Press.

Goldstone J. A. Bates R. H., Epstein D. L., Gurr T.R., Marshall M. G., Lustik M. B., Woodward M., Ulfelder J. (2010) A Global Model for Forecasting Political Instability. American Journal of Political Science, vol. 54, no 1, pp. 190-208.

Grinin L., Issaev L., Korotayev A. (2015) Revolyutsii i nestabil'nost' na Blizhnem Vostoke [Revolutions and Instability in the Near East], Moscow: Uchitel. 
Grinin L., Korotayev A. (2009). Urbanizacija i politicheskaja nestabil'nost': k razrabotke matematicheskih modelej politicheskih processov [Urbanization and Political Instability: Toward the development of Mathematical Models of Political Processes]. Political Studies, no 4, pp. 34-52.

Grinin L., Korotayev A. (2012). Tsikly, krizisy, lovushki sovremennoj Mir-Sistemy: issledovanie kondrat'evskikh, zhyuglyarovskikh i vekovykh tsiklov, global'nykh krizisov, mal'tuzianskikh i postmal'tuzianskikh lovushek [Cycles, Crises, Traps of the Modern World-System: Study of the Kondratieff, Juglar and Secular Cycles, Global Crises, Malthusian and Post-Malthusian Traps], Moscow: URSS.

Grinin L., Korotayev A. (2014) Revolution and Democracy in the Context of the Globalization. Dialectics of Modernity - Recognizing Globalization: Studies on the Theoretical Perspectives of Globalization (ed. E. Kiss), Budapest: Arisztotelész Kiadó.

Gurr T. R. (1968) A Causal Model of Civil Strife: A Comparative Analysis Using New Indices. American Political Science Review, vol. 62, no 4, pp. 1104-1124.

Gurr T. R. (1974) Persistence and Change in Political Systems, 1800-1971. American Political Science Review, vol. 68, no 4, pp. 1482-1504.

Gurr T. R. (2015) Why Men Rebel, London: Routledge.

Gurr T. R., Duvall R. (1973) Civil Conflict in the 1960s: A Reciprocal Theoretical System with Parameter Estimates. Comparative Political Studies, vol. 6, no 2, pp. 135-169.

Gurr T. R., Lichbach M. I. (1979) Forecasting Domestic Political Conflict. To Augur Well: Early Warning Indicators in World Politics (eds. J. Singer, M. Wallace), London: SAGE, pp. 153-194.

Hey J. D., Lambert P. J. (1980) Relative Deprivation and the Gini Coefficient: Comment. Quarterly Journal of Economics, vol. 95, no 3, pp. 567-573.

Huntington S. (1968) Political Order in Changing Societies, New Haven: Yale University Press.

Huntington S. (2004) Politicheskij porjadokv menjajushhihsja obshhestvah [Political Order in Changing Societies], Moscow: Progress-Tradition.

Hardy M. A. (1979) Economic-Growth, Distributional Inequality, and Political-Conflict in Industrial-Societies. Journal of Political \& Military Sociology, vol. 7, no 2, pp. 209227.

Knutsen C. H. (2014). Income Growth and Revolutions. Social Science Quarterly, vol. 95, no 4 , pp. 920-937.

Korotayev A. (2009) Compact Mathematical Models of the World System Development and Their Applicability to the Development of Local Solutions in Third World Countries. Systemic Development: Local Solutions in a Global Environment (ed. J. Sheffield), Litchfield Park: ISCE, pp. 103-116.

Korotayev A., Biljuga S., Shishkina A. (2016) VVP na dushu naselenija, uroven' protestnoj aktivnosti i tip rezhima: opyt kolichestvennogo analiza [GDP Per Capita, Protest Intensity and Regime Type: A Quantitative Analysis]. Comparative Politics, no 4, pp. 72-94. 
Korotayev A., Biljuga S., Shishkina A. (2017a) VVP na dushu naselenija, intensivnost' antipravitel'stvennyh demonstracij i uroven' obrazovanija: kross-nacional'nyj analiz [GDP Per Capita, the Intensity of the Anti-Government Demonstrations and Education Level: A Cross-National Analysis]. Politia, no 1, pp. 127-143.

Korotayev A., Biljuga S., Shishkina A. (2017b) Jekonomicheskij rost i social'no-politicheskaja destabilizacija: opyt global'nogo analiza [Economic Growth and Sociopolitical Destabilization: The Experience of Global Analysis]. Political Studies, no 2, pp. 155169.

Korotayev A., Grinin L., Isaev L., Zinkina Y., Vaskin I., Biljuga S., Slinko E., Meshcherina K. (2016) Destabilizacija: global'nye, nacional'nye, prirodnye faktory $i$ mehanizmy [Destabilization: Global, National, Natural Factors and Mechanisms], Moscow: Uchitel.

Korotayev A., Issaev L., Vasiliev A. (2015). Kolichestvennyj analiz revolyutsionnoj volny 2013-2014 gg. [Quantitative Analysis of the Revolutionary Wave of 2013-2014]. Sociological Studies, no 8, pp. 119-127.

Korotayev A., Issaev L., Zinkina J. (2015) Center-Periphery Dissonance as a Possible Factor of the Revolutionary Wave of 2013-2014: A Cross-National Analysis. Cross-Cultural Research, vol. 49, no 5, pp. 461-488.

Korotayev A., Malkov S., Burova A., Zinkina Y., Khodunov A. (2012) Lovushka na vykhode iz lovushki: matematicheskoe modelirovanie sotsial'no-politicheskoi destabilizatsii v stranakh mir-sistemnoi periferii i sobytiya Arabskoi vesny $2011 \mathrm{~g}$. [A Trap at the Escape from the Trap: Mathematical Modeling of Sociopolitical Destabilization in the World System Periphery Countries and the Arab Spring Events of 2011]. Modelirovanie i prognozirovanie global'nogo, regional'nogo i natsional'nogo razvitiya [Modeling and Forecasting Global, Regional, and National Development] (eds. A. Akaev, A. Korotaev, G. Malinetsky, S. Malkov), Moscow: Librokom, pp. 210-276.

Korotayev A., Vaskin I., Biljuga S. (2017). Gipoteza Olsona-Hantingtona o krivolinejnoj zavisimosti mezhdu urovnem jekonomicheskogo razvitija i social'no-politicheskoj destabilizaciej: opyt kolichestvennogo analiza [Olson-Huntington Hypothesis on a Bell-Shaped Relationship between the Level of Economic Development and Sociopolitical Destabilization: A Quantitative Analysis]. Russian Sociological Review, vol. 16, no 1, pp. 9-49.

Kuznets S. (1955) Economic Growth and Income Inequality. American Economic Review, vol. 45, no 1, pp. 1-28.

Lempert D. (2016) Predicting Political Systems Using Economic, Environmental, and Relational Variables. Social Evolution \& History, vol. 15, no 2, pp. 164-193.

MacCulloch R. (2004) The Impact of Income on the Taste for Revolt. American Journal of Political Science, vol. 48, no 4, pp. 830-848.

MacCulloch R. (2005) Income Inequality and the Taste for Revolution. Journal of Law and Economics, vol. 48, no 1, pp. 93-123.

MacCuloch R., Pezzini S. (2010) The Role of Freedom, Growth and Religion in the Taste for Revolution. Journal of Law and Economics, vol. 53, no 2, pp. 329-358. 
Marshall M. G., Cole B. R. (2008) A Macro-Comparative Analysis of the Problem of Factionalism in Emerging Democracies. Paper presented at the 2008 Annual Meeting of the American Political Science Association.

McAdam D. (2010) Political Process and the Development of Black Insurgency, 1930-1970, Chicago: University of Chicago Press.

Mealy M., Stephan W. G., Mhaka-Mutepfa M., Alvarado-Sanchez L. (2015) Interpersonal Trust in Ecuador, the United States, and Zimbabwe. Cross-Cultural Research, vol. 49, no 4, pp. 393-421.

Midlarsky M. I. (1988) Rulers and the Ruled: Patterned Inequality and the Onset of Mass Political Violence. American Political Science Review, vol. 82, no 2, pp. 491-509.

Miguel E., Satyanath S., Sergenti E. (2004) Economic Shocks and Civil Conflict: An Instrumental Variables Approach. Journal of Political Economy, vol. 112, no 4, pp. 725753 .

Mitchell E. J. (1968) Inequality and Insurgency: A Statistical Study of South Vietnam. World Politics, vol. 20, no 3, pp. 421-438.

Mitchell E. J. (1969) Some Econometrics of the Huk Rebellion. American Political Science Review, vol. 63, no 4, pp. 1159-1171.

Moaddel M. (1994) Political Conflict in the World Economy: a Cross-National Analysis of Modernization and World-System Theories. American Sociological Review, vol. 59, no 2, pp. 276-303.

Morgan W. R., Clark T. N. (1973) The Causes of Racial Disorders: a Grievance-Level Explanation. American Sociological Review, vol. 38, no 5, pp. 611-624.

Moore B. (1966) Social Origins of Dictatorship and Democracy, Boston: Beacon Press.

Moore B. (1978) Injustice: The Social Bases of Obedience and Revolt, White Plains: ME Sharpe.

Muller E. N. (1985) Income Inequality, Regime Repressiveness, and Political Violence. American Sociological Review, vol. 50, no 1, pp. 47-61.

Muller E. N., Seligson M. A. (1987) Inequality and Insurgency. American Political Science Review, vol. 81, no 2, pp. 425-451.

Nagel J. (1974) Inequality and Discontent: A Nonlinear Hypothesis. World Politics, vol. 26, no 4 , pp. 453-472.

Nel P. (2003) Income Inequality, Economic Growth, and Political Instability in Sub-Saharan Africa. Journal of Modern African Studies, vol. 41, no 4, pp. 611-639.

Nepal M., Bohara A. K., Gawande K. (2011) More Inequality, More Killings: The Maoist Insurgency in Nepal. American Journal of Political Science, vol. 55, no 4, pp. 886-906.

Nisbet R. A. (1968) Tradition and Revolt, New Jersey: Transaction.

Olson M. (1963) Rapid Growth as a Destabilizing Force. Journal of Economic History, vol. 23, no 4, pp. 529-552.

Østby G. (2008) Polarization, Horizontal Inequalities and Violent Civil Conflict. Journal of Peace Research, vol. 45, no 2, pp. 143-162. 
Østby G., Urdal H. (2010) Education and Civil Conflict: A Review of the Quantitative, Empirical Literature. Background Paper to UNESCO's Education for All Global Monitoring Report 2011.

Paranzino D. (1972) Inequality and Insurgency in Vietnam: A Further Re-Analysis. World Politics, vol. 24, no 4, pp. 565-578.

Parvin M. (1973) Economic Determinants of Political Unrest: An Econometric Approach. Journal of Conflict Resolution, vol. 17, no 2, pp. 271-91.

Perotti R. (1996) Growth, Income Distribution, and Democracy: What the Data Say. Journal of Economic Growth, vol. 1, no 2, pp. 149-187.

Prosterman R. L. (1976) "IRI": A Simplified Predictive Index of Rural Instability. Comparative Politics, vol. 8, no 3, pp. 339-353.

Russett B. M. (1964) Inequality and Instability: The Relation of Land Tenure to Politics. World Politics, vol. 16, no 3, pp. 442-454.

Russo A. J. (1968) Economic and Social Correlates of Government Control in South Vietnam, California: RAND Corporation.

Schock K. (1996) A Conjunctural Model of Political Conflict: The Impact of Political Opportunities on the Relationship between Economic Inequality and Violent Political Conflict. Journal of Conflict Resolution, vol. 40, no 1, pp. 98-133.

Sigelman L., Simpson M. (1977) A Cross-National Test of the Linkage Between Economic Inequality and Political Violence. Journal of Conflict Resolution, vol. 21, no 1, pp. 105128.

Singer J. D., Wallace M. D. (1979) To Augur Well: Early Warning Indicators in World Politics, London: SAGE.

Smith, B. (2004). Oil Wealth and Regime Survival in the Developing World, 1960-1999. American Journal of Political Science, vol. 48, no 2, pp. 232-246.

Tanter R., Midlarsky M. (1967) A Theory of Revolution. Journal of Conflict Resolution, vol. 9, no 3, pp. 264-280.

Temple J. (1998) Initial Conditions, Social Capital and Growth in Africa. Journal of African Economies, vol. 7, no 3, pp. 309-347.

Urnov M. (2008) Jemocii v politicheskom povedenii [Emotions in Political Behavior], Moscow: Aspect-Press.

Weede E. (1981) Income Inequality, Average Income, and Domestic Violence. Journal of Conflict Resolution, vol. 25, no 4, pp. 639-654.

Weede E. (1987) Some New Evidence on Correlates of Political Violence: Income Inequality, Regime Repressiveness, and Economic Development. European Sociological Review, vol. 3, no 2, pp. 97-108.

Wilson K. (2017) Cross-National Time-Series Data Archive: User's Manual, Jerusalem: Databanks International.

World Bank (2016a) GDP Per Capita, PPP (Constant 2011 International \$). World Development Indicators Online. Available at: http://data.worldbank.org/indicator/NY.GDP. PCAP.PP.KD (accessed: 24.12.2016). 
World Bank (2016b) GDP Per Capita Growth (Annual \%). World Development Indicators Online. Available at: http://data.worldbank.org/indicator/NY.GDP.PCAP.KD.ZG (accessed 24 May 2016).

World Bank (2016c) World Bank Atlas Method. Available at: https://datahelpdesk.worldbank.org/knowledgebase/articles/378832-the-world-bank-atlas-method-detailedmethodology (accessed 23 December 2016).

World Bank (2016d) World Bank Country and Lending Groups. Available at: https://datahelpdesk.worldbank.org/knowledgebase/articles/906519-world-bank-country-andlending-groups (accessed 23 December 2016).

World Bank (2016e) Historical Classification by Income in XLS Format. Available at: http://databank.worldbank.org/data/download/site-content/OGHIST.xls (accessed 23 December 2016).

World Bank (2017) Gini Index. World Development Indicators Online. Available at: http://data.worldbank.org/indicator/SI.POV.GINI (accessed 8 January 2017).

Yitzhaki S. (1979) Relative Deprivation and the Gini Coefficient. Quarterly Journal of Economics, vol. 93, no 2, pp. 321-324.

\title{
Экономическое развитие, социально-политическая дестабилизация и неравенство
}

\author{
Андрей Коротаев \\ Доктор философии (PhD), доктор исторических наук, профессор, заведующий лабораторией \\ мониторинга рисков социально-политической дестабилизации Национального исследовательского \\ университета «Высшая школа экономики» \\ Ведущий научный сотрудник Института востоковедения РАН \\ Адрес: ул. Мясницкая, д. 20, г. Москва, Российская Федерация 101000 \\ E-mail: akorotayev@gmail.com
}

\section{Леонид Гринин}

Доктор философских наук, главный научный сотрудник лаборатории мониторинга рисков социальнополитической дестабилизации Национального исследовательского университета «Высшая школа экономики»

Ведущий научный сотрудник Института востоковедения РАН

Адрес: ул. Мясницкая, д. 20, г. Москва, Российская Федерация 101000

E-mail: lgrinin@mail.ru

\section{Станислав Билюга}

Младший научный сотрудник лаборатории мониторинга рисков социально-политической дестабилизации Национального исследовательского университета «Высшая школа экономики» Адрес: ул. Мясницкая, д. 20, г. Москва, Российская Федерация 101000

E-mail: sbilyuga@gmail.com 


\section{Кира Мешерина}

Младший научный сотрудник лаборатории мониторинга рисков социально-политической дестабилизации Национального исследовательского университета «Высшая школа экономики» Младший научный сотрудник Института Африки РАН

Адрес: ул. Мясницкая, д. 20, г. Москва, Российская Федерация 101000

E-mail: k.meshcherina@hotmail.com

\section{Алиса Шишкина}

Младший научный сотрудник лаборатории мониторинга рисков социально-политической дестабилизации Национального исследовательского университета «Высшая школа экономики» Младший научный сотрудник Института Африки РАН

Адрес: ул. Мясницкая, д. 20, г. Москва, Российская Федерация 101000

E-mail: alisa.shishkina@gmail.com

Еще М. Олсон и С. Хантингтон предположили, что обнаруженная ими для слабои среднеразвитых стран положительная корреляция между подушевыми доходами и уровнем социально-политической нестабильности может частично объясняться ростом экономического неравенства по мере экономического развития в этих странах. Проведенная нами серия эмпирических тестов в общем и целом подтвердила обоснованность этой гипотезы. Вместе с тем наши тесты обнаружили и достаточно определенные пределы этого объяснения. Тесты выявили для экономически слабо- и среднеразвитых стран хоть и статистически значимую, но не слишком сильную положительную корреляцию между ВВП на душу населения и уровнем экономического неравенства. Между тем, ранее для этих же стран нами были выявлены заметно более сильные положительные корреляции с подушевым ВВП по некоторым важнейшим компонентам социально-политической дестабилизации, таким как интенсивность политических убийств, политических забастовок и антиправительственных демонстраций. Вполне очевидно, что сильно выраженную среди слабо- и среднеразвитых стран тенденцию к росту интенсивности этих компонентов социально-политической дестабилизации по мере экономического роста при помощи заметно более слабо выраженной тенденции к росту экономического неравенства можно объяснить в любом случае лишь в высшей степени частично. Кроме того, проведенные нами эмпирические тесты позволяют предполагать наличие на шкале индекса экономического неравенства Джини порогового значения в районе 40 пунктов, после прохождения которого наблюдается тенденция к скачкооброзному росту социально-политической дестабилизации в целом, и интенсивности террористических актов/«партизанских действий» и антиправительственных демонстраций в особенности. По данным Всемирного банка, Россия по данному показателю находится как раз в этой зоне, что заставляет предполагать, что дальнейший рост экономического неравенства в нашей стране может привести к скачкообразному росту политической нестабильности.

Ключевые слова: политическая нестабильность, социально-политическая дестабилизация, индексы дестабилизации CNTS, экономическое развитие, неравенство, ВВП на душу населения 